\title{
ARE WE READY FOR MOBILE LEARNING NOW? 2007 MOBILE LEARNING PREDICTIONS REVISITED
}

\author{
Joseph Rene Corbeil, The University of Texas at Brownsville, rcorbeil@utb.edu \\ Maria Elena Corbeil, The University of Texas at Brownsville, mariaelena.corbeil@utb.edu
}

\begin{abstract}
In an article titled, "Are You Ready For Mobile Learning?" published in 2007, the authors conducted a survey of mobile learning readiness amongst students and faculty in their online programs. Because of the timeliness of the topic, the article was published in EDUCAUSE Quarterly and was recognized as the magazine's "2007 Contribution of the Year." The 2007 study revealed that although 94 percent of the students indicated that they were technologically geared up, frequent use of mobile devices did not translate into readiness for mobile teaching and learning. Four years later, the mobile computing and communications landscape has evolved dramatically, putting smart mobile devices into the hands of more people. So, a burning question yearns to be asked, are we ready for mobile learning now? This article presents an overview of developments in mobile technologies from 2007 to the present; a comparison of the Mobile Learning Readiness Survey results from 2007 and 2011; an overview of the most significant barriers to mobile learning adoption; and a look ahead to the future of mobile learning to help IT professionals, administrators, and faculty in higher education overcome some of the barriers and incorporate diverse technologies and pedagogies in their programs.
\end{abstract}

Keywords: Mobile Learning, Mobile Computing, m-learning, e-learning, Educational Technology, Higher Education

\section{INTRODUCTION}

In the 2007 article, the authors predicted, "the next few years will see a period of rapid growth for mobile learning, with evolutionary rather than revolutionary changes [8]. Although they were correct about the rapid growth of mobile learning technologies, they were wrong about the changes being "evolutionary." The release of the iPhone ${ }^{\circledR}$ on June 29, 2007, ignited a worldwide race to develop the smartest, fastest, and most sophisticated smart phones the world has ever seen. Technologies that showed great potential in 2007, such as the ultra-mobile PC, launched by Microsoft and Intel in spring 2006, and the netbook, introduced in late 2007, have been eclipsed by newer, more powerful, mobile devices like the iPod touch ${ }^{\circledR}$, iPad ${ }^{\circledR}$, and smart e-book readers like Amazon's Kindle ${ }^{\circledR}$. Groundbreaking advancements were also observed in cellular and mobile broadband, as well as in small, portable cellular Wi-Fi devices that made it easier to access the Internet while on the move. With all of these technological improvements, one would expect that within the same time frame, mobile teaching and learning would also grow by leaps and bounds. Yet, as with all educational innovation, wide-scale adoption has been very slow and not yet fully realized. This article analyzes the Mobile Learning Readiness Survey results from 2007 and 2011; examines the advancements that have been made in mobile communications/computing technologies over the past four years; and describes current technological trends and how they may impact mobile learning adoption in the near future.

\section{MOBILE TECHNOLOGIES DEVELOPMENTS FROM 2007 TO 2011}

For years, pundits have been predicting that mobile learning was on the verge of taking off, as soon as the technology evolved to a point where mobile learning could be adequately supported. In 2007, mobile communications and computing devices were slow and expensive, with limited capabilities. Smart phones were not very smart, had tiny screens, and few applications. People primarily used their Blackberries ${ }^{\circledR}$, Palm ${ }^{\circledR}$, and Windows Mobile ${ }^{\circledR}$ devices for email, text messaging, listening to music, and light web browsing. Before widespread adoption of 3G, mobile broadband transmission rates were typically between 300-500 Kbps. Web browsing was mostly limited to "mobile friendly" web sites, which were stripped down, text-based web pages with minimal graphics for news, sports, weather, and stock updates. Since then, mobile broadband has increased to 3G (up to $3.17 \mathrm{Mbps}$ ) and 4G (up to $10 \mathrm{Mbps}$ ) speeds, smart phones have gotten much smarter, with more memory and speed, larger, touch-sensitive screens, advanced operating systems and sophisticated applications capable of leveraging the full 
power of the Internet. New tablet-based devices have also emerged in recent years that are capable of producing, as well as consuming, multimedia (text, audio, and video) content. If inadequate hardware and bandwidth were the primary barriers to full-scale adoption of mobile learning in 2007, the technological innovations that have emerged since then would put this barrier to rest.

The following section presents some of the most important innovations in mobile technology from 2007 to the present. This list is not intended to be comprehensive, but to provide an overview of the key events, services, and technologies that have evolved to make mobile teaching and learning more practical.

\section{7}

If one were to look back over the history of mobile learning, 2007 would be the year with the most significant advancements in mobile technology. The iPhone ${ }^{\circledR}$, released in June [6], jump-started the modern smartphone era. It was the first smart phone to include a multi-touch screen, media player, video and digital camera, voice recorder, and web browser. Later that year, Apple released the first generation iPod touch ${ }^{\circledR}[2]$ and announced that it would open iPhone ${ }^{\circledR}$ apps to $3^{\text {rd }}$ party developers [19], thereby increasing the functionality of its devices. Apple was not the only mobile technology player on the field in 2007. In October, ASUS released the EeePC® netbook [11]. Although the first netbooks had stripped down versions of the Linux or Windows XP operating systems, the EeePC ${ }^{\circledR}$ was considered a "milestone" because it launched the "netbook category of small, low cost laptops" [11]. Netbooks enabled mobile users to access the Internet and perform basic productivity tasks, such as respond to email and do light word processing, while on the go.

In 2007, email communication and social networking services were also key players in the expansion of mobile communications. Google released a previously private beta Gmail ${ }^{\circledR}$ to the public. It was the first "free search-based webmail service with a storage capacity of up to eight billion bits of information, the equivalent of 500,000 pages of email per user" [15]. Twitter also experienced exponential growth [14], due, in part, to two events that year: (1) the South by Southwest (SXSW) festival, during which Twitter "usage went from 20,000 tweets per day to 60,000" [14]; and the release of the iPhone ${ }^{\circledR}$ and iPod touch ${ }^{\circledR}$.

E-book readers also experienced a rebirth in 2007. In November, Amazon released the 1st generation Kindle ${ }^{\circledR}$, which, at a cost of \$399, sold out in less than six hours [23]. Although e-book readers had been in the market for several years, the Kindle ${ }^{\circledR}$ was different because it made it easy to preview, purchase, download and read digital texts. Thinner and lighter than a magazine, the Kindle ${ }^{\circledR}$ made it possible for people to take entire libraries of books, magazines and documents with them while traveling.

\section{8}

Although 2008 was a seemingly slower year in comparison to 2007, it was the year for increased accessibility to, and expanded services, for smart phones. With the release of the first Android ${ }^{\circledR}$ phone by T-Mobile in September [12], advanced smart phone features were no longer exclusively limited to iPhone ${ }^{\circledR}$ customers. Apple however, did not give up any ground. In July, it opened the App Store with approximately 500 apps for the iPhone ${ }^{\circledR}$ and iPod touch ${ }^{\circledR}$, as well as the second-generation iPhone ${ }^{\circledR}$ that was compatible with the new, more powerful 3G network [31].

\section{9}

In 2009, the stage was set for an expansion in mobile device platforms, cellular broadband, and e-learning services. In the spring, Research in Motion opened its own Blackberry ${ }^{\circledR}$ app store [21], Palm ${ }^{\circledR}$ launched WebOS [24], and Novatel introduced the first small, portable router $\left(\mathrm{MiFi}{ }^{\circledR}\right)$ in the United States to provide wireless Internet (Wi-Fi hotspots) to mobile devices [25]. Later that year, the world's first fully 4G capable network became available in Stockholm, Sweden [30]. This Fourth Generation (4G) mobile network allowed for high-speed data transmission and wireless broadband anywhere within its service areas. Seeing the growth potential for mobile learning, Moodle, an open-source courseware management system, released the Mobile Learning Engine (MLE Moodle) allowing its 
Volume XII, No. 2, pp 142-152, 2011

users to access their Moodle courses through their mobile devices [22].

2010

2010 was the year of the tablet. Apple released the iPad $®$ in April [3], followed closely by Samsung's Android OS Galaxy ${ }^{\circledR}$ tablet in September [13]. In July, Hewlett Packard acquired Palm ${ }^{\circledR}$ to begin developing its own tablet [7]. Several new smartphone platforms also appeared, including Google's Nexus One Android OS ${ }^{\circledR}$ phone [17], Microsoft's Windows Phone 7® [20], and Nokia's N8® smartphone (the first to use the new Symbian 3 operating system) [27]. Following Moodle's venture into e-learning, learning management system giant, Blackboard, quickly followed with the release of Blackboard Mobile Learn for Android ${ }^{\circledR}$, BlackBerry ${ }^{\circledR}$ and iPhone ${ }^{\circledR}$ OS powered devices [5].

2011

With more powerful, nationwide cellular networks, coupled with new hardware and advancements in file/content storage and design services, will 2011 be the year in which mobile learning finally launches? One of the most significant advancements of the year will no doubt be the expansion of 4G networks across all cellular carriers, and the proliferation of next generation of 4G-enabled smart phones and tablets. Cloud computing will also continue to grow as technology giants like Google (Mail and Docs) and Apple (MobileMe and iTunes) continue to expand their cloud presence. Productivity software for creating mobile content will also grow in 2011. For example, in July, SoftChalk 7 will feature two new mobile learning tools: (1) Smart Mobile- a tool that automatically reformats SoftChalk content for viewing in mobile devices; and (2) CONNECT Plus- a "cloud-based, Learning Object Repository" [33]. In addition to the release of the second-generation iPad ${ }^{\circledR}$ [29], over a dozen new tablets were announced, including the Motorola Xoom ${ }^{\circledR}$ [28] and the Blackberry PlayBook ${ }^{\circledR}$ [26]. Just as the phenomenal growth of netbooks from 2007 to 2009 was considered a milestone in its time, the growth of tablets in the coming years will undoubtedly make them the device of choice for many mobile learners.

Technologically, mobile learning has made great progress over the past 4 years and is reaching a point where the tools and services are affordable and accessible to a majority of learners and instructors. The exponential growth in the availability of a myriad of mobile devices and applications has driven fast-paced learning. As a result, an increasing number of teenagers and adults already possess the know-how capable of facilitating mobile learning.

\section{READINESS FOR MOBILE LEARNING: THEN AND NOW (2007-2011)}

To determine if there was a change in the readiness for mobile learning among distance learning students and faculty between 2007 and 2011, a survey of student and faculty ownership, use, and readiness was conducted from April 18 to May 3, 2011. The Mobile Learning Readiness Survey was made available to students enrolled in 24 online courses through a posting on an educational technology blog site. Of the population of 263 graduate and undergraduate students, 74 students (35.5\%) volunteered to participate in the survey. Seventy-one full and part time university faculty also took part in the survey.

The survey asked three multiple-choice questions:

1. Which of the following mobile computing/ communication devices do you currently own?

2. Which of the following mobile computing/ communication activities do you regularly engage in?

3. Do you think you are you ready for mobile learning?

A fourth, open-ended question asked participants to elaborate on why they believed they were/were not ready for mobile learning. The two surveys were the same, except the 2011 questions were updated to include new mobile technologies and activities that have emerged since the 2007 survey was conducted. 
Volume XII, No. 2, pp 142-152, 2011

Table 1 provides a summary of the results for Question 1 regarding mobile device ownership for students and faculty in 2007 and 2011. Three new mobile devices, including the netbook, tablet, and Wi-Fi modem, were added to the 2011 survey to bring it up to date with some of the most common devices in use today.

Table 1. Summary of survey results for students and faculty mobile device ownership in 2007 and 2011

\begin{tabular}{|c|c|c|c|c|c|c|c|c|c|c|}
\hline \multirow{3}{*}{$\begin{array}{l}\text { Q1. Which of the } \\
\text { following mobile } \\
\text { computing/ } \\
\text { communication devices } \\
\text { do you currently own? }\end{array}$} & \multicolumn{5}{|c|}{ Students } & \multicolumn{5}{|c|}{ Faculty } \\
\hline & \multicolumn{2}{|c|}{$\begin{array}{c}2007 \\
N=107\end{array}$} & \multicolumn{2}{|c|}{$\begin{array}{c}2011 \\
N=74\end{array}$} & \multirow[b]{2}{*}{ Change } & \multicolumn{2}{|c|}{$\begin{array}{c}2007 \\
N=\mathbf{2 9}\end{array}$} & \multicolumn{2}{|c|}{$\begin{array}{c}2011 \\
N=71\end{array}$} & \multirow[b]{2}{*}{ Change } \\
\hline & $N$ & $\%$ & $N$ & $\%$ & & $N$ & $\%$ & $N$ & $\%$ & \\
\hline iPod $\AA$ & 36 & 33.6 & 39 & 52.7 & 19.1 & 6 & 20.7 & 31 & 43.7 & 23.0 \\
\hline MP3 Player & 58 & 54.2 & 26 & 35.1 & -19.1 & 4 & 13.8 & 33 & 46.5 & 32.7 \\
\hline PDA & 51 & 47.7 & 9 & 12.2 & -35.5 & 8 & 27.6 & 15 & 21.1 & -6.5 \\
\hline USB Drive & 76 & 71.0 & 49 & 66.2 & -4.8 & 20 & 69.0 & 60 & 84.5 & 15.5 \\
\hline E-book Reader & 11 & 10.3 & 13 & 17.6 & 7.3 & 1 & 3.4 & 20 & 28.2 & 24.8 \\
\hline Cell Phone & 97 & 90.7 & 48 & 64.9 & -25.8 & 26 & 89.7 & 34 & 47.9 & -41.8 \\
\hline Smart Phone & 20 & 18.7 & 41 & 55.4 & 36.7 & 2 & 6.9 & 46 & 64.8 & 57.9 \\
\hline UMPC & 4 & 3.7 & 4 & 5.4 & 1.7 & 0 & 0.0 & 3 & 4.2 & 4.1 \\
\hline Laptop & 98 & 91.6 & 64 & 86.5 & -5.1 & 25 & 86.2 & 63 & 88.7 & 2.5 \\
\hline Handheld Gaming System & 31 & 29.0 & 19 & 25.7 & -3.3 & 2 & 6.9 & 9 & 12.7 & 5.8 \\
\hline Netbook & & & 7 & 9.5 & 9.5 & & & 16 & 22.5 & 22.5 \\
\hline Tablet & & & 5 & 6.8 & 6.8 & & & 21 & 29.6 & 29.6 \\
\hline Wi-Fi Modem & & & 17 & 23.0 & 23.0 & & & 17 & 23.9 & 23.9 \\
\hline
\end{tabular}

For students, during the 4 year period, iPod ${ }^{\circledR}$ ownership increased by $19.1 \%$, while MP3 Player ownership dropped by the same percentage points. Likewise, while cell phone ownership decreased from $90.7 \%$ in 2007 to $64.9 \%$ in 2011, smartphone ownership increased by 36.7\% from 2007 to 2011. Interestingly, laptop ownership decreased from $91.6 \%$ in 2007 to $86.5 \%$ in 2011, while netbook ownership increased from $0 \%$ to $9.5 \%$ during the same time period. Today, $6.8 \%$ of students own tablets and $23 \%$ own mobile Wi-Fi modems.

During the same period, faculty ownership of: iPods ${ }^{\circledR}$ increased by $23 \%$; MP3 players increased by $32.7 \%$; USB drives increased by $15.5 \%$; and laptops increased by just $2.5 \%$. Presently, $22.5 \%$ of faculty own netbooks and $29.6 \%$ own tablets. Cell phone ownership dropped from $89.7 \%$ in 2007 to $47.9 \%$ in 2011. Conversely, smart phone ownership increased by $57.9 \%$ from $6.9 \%$ in 2007 to $64.8 \%$ in 2011 . Among faculty, ownership of e-book readers increased from $3.4 \%$ in 2007 to $28.2 \%$ in 2011.

Table 2 presents a summary of the 2007 and 2011 results of the question regarding the mobile activities students and faculty regularly engaged in. Five new mobile activities were added to the 2011 survey: posting status updates to social media sites (Facebook, Twitter); saving files in cloud storage (Dropbox, MobileMe,); mobile video conferencing (Skype, FaceTime); browsing the web; and working collaboratively on shared documents (Google docs, wiki). 
Volume XII, No. 2, pp 142-152, 2011

Table 2. Summary of survey results for students and faculty mobile activities in 2007 and 2011

\begin{tabular}{|c|c|c|c|c|c|c|c|c|c|c|}
\hline \multirow{3}{*}{$\begin{array}{l}\text { Question } 2 . \\
\text { Which of the following } \\
\text { mobile computing/ } \\
\text { communication activities } \\
\text { do you regularly engage } \\
\text { in? }\end{array}$} & \multicolumn{5}{|c|}{ Students } & \multicolumn{5}{|c|}{ Faculty } \\
\hline & \multicolumn{2}{|c|}{$\begin{array}{c}2007 \\
N=107 \\
\end{array}$} & \multicolumn{2}{|c|}{$\begin{array}{c}2011 \\
N=74 \\
\end{array}$} & \multirow[b]{2}{*}{ Change } & \multicolumn{2}{|c|}{$\begin{array}{c}\mathbf{2 0 0 7} \\
N=\mathbf{2 9} \\
\end{array}$} & \multicolumn{2}{|c|}{$\begin{array}{c}2011 \\
N=71 \\
\end{array}$} & \multirow[b]{2}{*}{ Change } \\
\hline & $N$ & $\%$ & $N$ & $\%$ & & $N$ & $\%$ & $N$ & $\%$ & \\
\hline $\begin{array}{l}\text { Listen to podcasts/audio } \\
\text { books }\end{array}$ & 29 & 27.1 & 25 & 33.8 & 6.7 & 6 & 20.7 & 38 & 53.5 & 32.8 \\
\hline $\begin{array}{l}\text { Read e-books/print-based } \\
\text { content }\end{array}$ & 32 & 29.9 & 26 & 35.1 & 5.2 & 8 & 27.6 & 34 & 47.9 & 20.3 \\
\hline $\begin{array}{l}\text { View streaming } \\
\text { movies/video clips }\end{array}$ & 69 & 64.5 & 48 & 64.9 & 0.4 & 8 & 27.6 & 48 & 67.6 & 40.0 \\
\hline Send and receive email & 105 & 98.1 & 67 & 90.5 & -7.6 & 29 & $\begin{array}{c}100 . \\
0\end{array}$ & 69 & 97.2 & -2.8 \\
\hline $\begin{array}{l}\text { Send and receive instant } \\
\text { messages (IMs) }\end{array}$ & 60 & 56.1 & 48 & 64.9 & 8.8 & 8 & 26.6 & 41 & 57.7 & 30.1 \\
\hline $\begin{array}{l}\text { Send and receive short text } \\
\text { messages (SMS) }\end{array}$ & 48 & 44.9 & 59 & 79.7 & 34.8 & 4 & 13.8 & 59 & 83.1 & 69.3 \\
\hline $\begin{array}{l}\text { Transfer files via portable } \\
\text { storage devices (USB } \\
\text { drives) }\end{array}$ & 88 & 82.2 & 49 & 66.2 & -16.0 & 23 & 79.3 & 56 & 78.9 & -0.4 \\
\hline $\begin{array}{l}\text { Play interactive games via } \\
\text { the Internet }\end{array}$ & 34 & 31.8 & 26 & 35.1 & 3.3 & 1 & 3.4 & 15 & 21.1 & 17.7 \\
\hline $\begin{array}{l}\text { Use smart phone as file } \\
\text { transfer/storage device }\end{array}$ & 51 & 47.7 & 24 & 32.4 & -15.3 & 6 & 20.7 & 21 & 29.6 & 8.9 \\
\hline $\begin{array}{l}\text { Post status updates to } \\
\text { social media sites } \\
\text { (Facebook, Twitter) }\end{array}$ & & & 47 & 63.5 & 63.5 & & & 46 & 64.8 & 64.8 \\
\hline $\begin{array}{l}\text { Save files in cloud storage } \\
\text { (Dropbox, MobileMe,) }\end{array}$ & & & 17 & 23.0 & 23.0 & & & 38 & 53.5 & 53.5 \\
\hline $\begin{array}{l}\text { Mobile video conferencing } \\
\text { (Skype, FaceTime) }\end{array}$ & & & 29 & 39.2 & 39.2 & & & 37 & 52.1 & 52.1 \\
\hline Browse the web & & & 64 & 86.5 & 86.5 & & & 67 & 94.4 & 94.4 \\
\hline $\begin{array}{l}\text { Work collaboratively on } \\
\text { shared documents (Google } \\
\text { docs, wiki) }\end{array}$ & & & 38 & 51.4 & 51.4 & & & 44 & 62.0 & 62.0 \\
\hline
\end{tabular}

From 2007 to 2011, most student mobile activities increased. For example: listening to podcasts and audiobooks increased by $6.7 \%$; reading e-books and print-based content increased by $5.2 \%$; viewing streaming movies and video clips increased by $.04 \%$; and instant messaging increased by $8.8 \%$. Yet, during the same time period, student use of email decreased by $7.6 \%$, while short text messaging (SMS) increased by $34.8 \%$. Currently, $23 \%$ of students use cloud storage to save files for easy access between computers and mobile devices; $86.5 \%$ use their mobile devices to browse the Web; $51.4 \%$ work collaboratively on shared documents; and $86.5 \%$ post regular status updates to social media sites.

Faculty also showed dramatic increases in participation in many mobile activities, some of which their students have been engaging in at high levels for many years. For example, listening to podcasts and audio books increased by $32.8 \%$; reading e-books and print-based content online grew by $20.3 \%$; and watching streamed movies and video clips increased by $40 \%$. In addition, faculty use of instant messaging grew by $30.1 \%$, while text messaging increased from $13.8 \%$ in 2007 to $83.1 \%$ in 2011 , for a $69.3 \%$ increase. Over the past 4 years, email use among faculty dropped by $2.8 \%$. Today, $52.1 \%$ of faculty use their mobile devices to videoconference, $94.4 \%$ browse the web, and $62 \%$ work collaboratively on shared documents. In many respects, faculty use of mobile devices has grown faster, and in some instances, has outpaced their students' use of mobile devices. Table 3 presents a summary of the results for survey Question 3. 
Volume XII, No. 2, pp 142-152, 2011

Table 3. Summary of survey results for students and faculty mobile learning readiness in 2007 and 2011

\begin{tabular}{|c|c|c|c|c|c|c|c|c|c|c|}
\hline \multirow{3}{*}{$\begin{array}{l}\text { Question } 3 \text {. Do you } \\
\text { think you are you ready } \\
\text { for mobile learning? }\end{array}$} & \multicolumn{5}{|c|}{ Students } & \multicolumn{5}{|c|}{ Faculty } \\
\hline & \multicolumn{2}{|c|}{$\begin{array}{c}2007 \\
N=107\end{array}$} & \multicolumn{2}{|c|}{$\begin{array}{c}2011 \\
N=74\end{array}$} & \multirow[b]{2}{*}{ Change } & \multicolumn{2}{|c|}{$\begin{array}{c}2007 \\
N=29\end{array}$} & \multicolumn{2}{|c|}{$\begin{array}{c}2011 \\
N=71\end{array}$} & \multirow[b]{2}{*}{ Change } \\
\hline & $N$ & $\%$ & $N$ & $\%$ & & $N$ & $\%$ & $N$ & $\%$ & \\
\hline Yes & 100 & 93.5 & 61 & 82.4 & -11.1 & 18 & 62.1 & 57 & 80.3 & 18.2 \\
\hline No & 7 & 6.5 & 13 & 17.6 & 11.1 & 11 & 37.9 & 14 & 19.7 & -18.2 \\
\hline
\end{tabular}

As shown in Table 3, student and faculty perceptions of readiness for mobile learning unexpectedly switched between 2007 and 2011. In 2007, 93.5\% of students indicated that they were ready for mobile learning, compared to only $82.4 \%$ in 2011 for an $11.1 \%$ decrease. Conversely, faculty readiness for mobile learning increased from $62.1 \%$ in 2007 to $80.3 \%$ for an increase of $18.2 \%$. Based on the results of this survey, faculty have closed the gap on ownership, use, and readiness for mobile learning over the past 4 years.

Question 4 asked students and faculty to elaborate on their readiness for mobile learning. The 2011 survey responses were broken down into two groups: students and faculty. The group responses were further broken down into two categories, those who thought they were ready for mobile learning, and those who did not think they were ready for mobile learning. Below is a sample of the results.

\section{Student Responses}

The following is a sample of responses from students who believed they were not ready for mobile learning:

- I am all for my smartphone and online learning. However, there are still issues with apps and Internet connections on my phone that need to be worked out before I could rely on using it for a grade. Using it as a tool, staying up on email or posting a comment on the discussion board, those types of tasks would be wonderful to access on my phone. But any types of assignment that need more than one tab in my browser, or are more than a paragraph long, or require uploading larger files, those "heavy lifting" tasks aren't ready for the $2 "$ 2 $\quad x \quad 3 "$ screen

- Currently, I do not own a mobile platform device I could use for serious learning. The Blackberry ${ }^{\circledR}$ is a corporate issued device and is not ready for prime time relative to mobile learning...or pretty much, mobile anything. I plan to purchase a tablet this summer and am waiting on iPad v3® or the next iteration of Android ${ }^{\circledR}$ on an HTC ${ }^{\circledR}$ tablet.

The following is a sample of responses from students who believed they were ready for mobile learning:

- I have been using devices to check my homework, and lessons. I am comfortable with using any of these devices to do learning. I am using my smartphone to answer this survey.

- I'm surprised mobile learning isn't in effect as of now. I already take online classes. I would love taking mobile classes. It seems like the next step.

- Some things I already do from my Blackberry ${ }^{\circledR}$, like complete this survey, check email, and surf the web. Since my job does not allow employees to use the computer for personal use, I have to use my Blackberry ${ }^{\circledR}$ to check school email. It would be nice if I could do more schoolwork on the go.

- I'm already working with these devices for similar activities so why not for education. 
Volume XII, No. 2, pp 142-152, 2011

\section{Faculty Responses}

The following is a sample of responses from faculty who believed they were not ready for mobile learning:

- I feel I have sufficient technical skills - however, that assumption is based on my COMPUTER skills -mobile may be entirely different. Or, it may be just too dang small to see! \{Price to pay for these over 40 eyes!\}

- I already participate in mobile learning via online courses. It is convenient to complete my coursework wherever I am located, whether home, at work, or on vacation. However, I am not ready to use anything other than web content at this point. I do not have a handheld device capable of running apps and even when accessing Blackboard on a borrowed iPod touch ${ }^{\circledR}$ at one point, I found the interface difficult to use in miniature.

- It depends on what we expect from mobile learning. And what you mean by ready... ready to participate or to produce/adapt my courses for mobile learning? Yes I am ready to participate, but not really ready to adapt all my courses to small screens... and mobile learning constraints.

- I like the idea of mobile learning. I think it clearly fits into today's culture and practices. However, I would need training and ongoing support in order to be an effective teacher. I worry about my personal costs given that I own very few devices that would be considered mobile. Also, I do not want to be connected to my students $24 / 7$. I like being able to retreat into privacy.

The following is a sample of responses from faculty who believed they were ready for mobile learning:

- I regularly teach using my smart phone and laptop. Through a live chat app, I am available to students and provide just-in-time support and instruction at times that are convenient to them. I can also share content and resources with them and colleagues. Increasingly, more of my students and I use our smart phones regularly to collaborate in the courses through the Blackboard app, email, instant messaging and cloud computing. However, I have to work more deliberately on developing course content that is easily accessible on students' smart phones.

- Regardless of what form mobile learning actually takes on, I am able to access, download, upload, read, view, watch, listen, and interact with just about anything via my 3/4G network or multiple, readily accessible Wi-Fi hotspots (Starbucks, Amtrak, Southwest Airlines, or at home). With an array of devices such as my laptop, tablet, and smartphone, I feel I can do just about anything my classes require from just about anywhere. In fact, I'm taking this survey on my smartphone. Case in point, I think.

\section{RESULTS, CONCLUSIONS, AND IMPLICATIONS}

Although a significant majority of students and faculty indicated that they had the tools, experience, and know-how for mobile learning (82.4\% of students and $80.3 \%$ of faculty), a sizable group of students and faculty (17.6\% of students and $19.7 \%$ of faculty), indicated that they had reservations about their and/or the platform's readiness for mobile learning. While, today, more faculty indicated their willingness and readiness for mobile learning, student readiness dropped by $11.1 \%$. Some students and faculty who expressed reservations regarding mobile learning were concerned with the limitations of the hardware (i.e., small screen size, limited power, high cost, etc.), as well as restrictions on the delivery of some types of content (i.e., Flash, large text files, etc.). Others expressed concerns over lack of pedagogy and best practices in designing instruction suitable for mobile teaching and learning. Yet, despite these concerns, a significant majority of faculty and students expressed a willingness to explore mobile learning and its potential for enhancing instruction, both in and out of the classroom. 
Volume XII, No. 2, pp 142-152, 2011

\section{BARRIERS TO MOBILE LEARNING ADOPTION}

Four years after the Are You Ready for Mobile Learning? article [8] was published, mobile learning stills appears to be on the cusp of taking off, yet adoption seems to be moving much slower than the authors anticipated and most pundits predicted. Herrington, et al., noted, "While mobile technologies such as mobile phones, personal digital assistants (PDAs) and digital music players (mp3 players) have permeated popular culture, they have not found widespread acceptance as pedagogical tools in higher education” [16]. Now that the technology exists to support mobile learning and the mobile communication and computing tools are more affordable, there still seem to be some significant barriers to adoption for institutions of higher education.

Research $[10,9,18]$ revealed that in higher education, there are two major areas that present challenges to widespread mobile learning adoption: (1) Technological Infrastructure, and (2) Faculty Training. The technological infrastructure includes the need for institution-wide support to redesign the IT infrastructure, so it can provide sustained technical support for the increasing variety of mobile devices, platforms, and content types. In an EDUCAUSE Conversations [10] podcast, Alexander compared providing IT support in the past and today. He noted, "It used to be that we could assume a simple universe of Windows and PC, plus MAC, and that was it." Today, with the increasing variety of phones, audio/video players, gaming devices, e-book readers, and more, he [10] added, "the number and type of categories has just expanded and is leading to increase in demands of complexity for IT." Alexander [10] also observed that the prospect of mobile computing tools such as apps is not all bleak, as HTML 5 shows promise in alleviating the current challenges. However, he [10] warned that HTML 5 is still in its infancy and recommended that higher education institutions stick to web content for now and carefully weigh the costs versus the benefits of mobile technologies, very carefully.

For the second barrier, instead of addressing only training, the authors prefer to use the term faculty readiness. In their experience, readiness for mobile learning, includes not only the need for ongoing training and mentoring in mobile learning technologies and pedagogies, but instructors' readiness to embrace a new paradigm of teaching and learning; and build into their courses (and lives), the flexibility and support that mobile students require. In the openended question of the 2011 Mobile Learning Readiness Survey, many faculty expressed the need for training as a challenge to implementation. The issues and barriers related to mobile learning in higher education, although worthwhile as more companies and people use mobile technologies in their personal and professional lives, are complex and require careful research and consideration.

\section{LOOKING AHEAD}

The exponential growth of the availability and rate of use of mobile devices in the next several years will drive the implementation of mobile learning in higher education. Industry and business have caught on to the power of mobile computing. Yet IT, Computer Science, Business, and Education programs in higher education struggle with the challenges of implementing mobile learning. However, they have an increasing responsibility to prepare graduates for the skills they will need, and are actually already using in the workforce. What's more, students come to the learning environment, oftentimes having and using more technologies and mobile skills than their instructors. The following trends in mobile technologies will help higher education programs capitalize on the benefits of mobile computing to reach more students and help them learn in increasingly dynamic ways that are relevant to their personal and professional lives.

Print resources are going digital. More printed resources, including journals, magazines, and books are moving to digital formats, making it easier to access these resources through a mobile device. With companies such as Apple [4] and Amazon [1] boasting collections of over 200,000 and 900,000 digital resources respectively, advertisers are quickly following the readers. A study published in Forbes Magazine [32] in March 2010 reported that for the first time, U.S. advertisers spent more advertising dollars on digital media than print.

The number and quality of web applications is increasing. Presently, Word, Excel, and PowerPoint files are viewable through browser-enabled cell phones and smart phones. Likewise, Google Docs offers web-based word processing, spreadsheet, presentation, drawing, and form generation tools, enabling individuals working alone or in 
groups to create, edit, store and share documents online. A host of social media resources, including wikis, blogs, and file sharing sites accessible via mobile devices can also be used for creating and sharing work easily on the go.

Media storage is moving to the cloud. The availability of an increasing number of free cloud-based services, like Windows SkyDrive, Apple MobileMe, Amazon Simple Storage Service (Amazon S3), and Dropbox, make it easy to store and access content from nearly anywhere through mobile devices.

Video and audio streaming is increasing and becoming easier to use. Recent increases to broadband through availability of 3G/4G networks have made streaming of longer-form video more practical on mobile devices. Content creators are moving toward common formats, such as HTML 5 as an alternative to Adobe Flash, to make the content more accessible across mobile platforms.

E-Learning platforms are expanding to m-learning. E-learning systems and authoring programs are developing mobile alternatives for content delivery: Blackboard Mobile TM Learn for smartphones and tablets; MLE - Moodle; and course development software like SoftChalk 7.0, automatically generate mobile-enhanced versions of lesson materials.

Mobile devices are becoming more usable. Mobile devices have larger screens and improved methods for inputting information (i.e., larger keyboards - virtual and Bluetooth, improved voice recognition, and voice command features, etc.), making them suitable mobile productivity tools. Nearly every instructional task that can be accomplished on a laptop, can now be performed on a tablet, and to a lesser degree, on smart phones with large screens and usable keyboards.

Augmented reality tools are redefining informal learning in higher education and the workforce. Augmented realities were created as a counterpart to virtual realities [10]. Through augmented reality, instead of recreating real life in a virtual environment, digital content is superimposed over real world objects. For example, using a constellations app, users can point their smart phones toward the night sky and the corresponding constellations will appear superimposed over the stars. In a similar way, learners can point their smart phones toward buildings and have the blueprints appear over them. The educational applications for augmented reality are endless.

In summary, based on the aforementioned trends and the results of the Survey of Mobile Learning Readiness, that revealed that faculty and students are quickly closing the gap on ownership, use, and readiness for mobile learning, the future of mobile learning is bursting with potential. The possibilities for mobile learning both in higher education and in the workforce can best be summarized by Alexander [10], who said, "Science fiction is our best instructor...Think about a room... and the simple act of crossing it pulls down documents, changes a screen, sends a signal a different way. We are turning the entire space into a living medium we are just beginning to conceive.” Over the past four years, technology has evolved to the point where it can make mobile learning practical. Although there are still some barriers to overcome, the future looks very promising. So, the question remains, are we ready for mobile learning now?

\section{REFERENCES}

1. Amazon.com. (2011). Amazon Kindle store. Retrieved from http://www.amazon.com/kindle-store-ebooksnewspapers-blogs/b?ie=UTF8\&node $=133141011$

2. Apple.com. (2007, September 5). Apple unveils iPod touch. Retrieved from http://www.apple.com/pr/library/2007/09/05touch.html

3. Apple.com. (2010, March 5). Release date update. Retrieved from http://ipad.org/tag/ipad-release-date/

4. Apple.com. (2011). iBooks: Bury your nose in iBooks. Retrieved from http://www.apple.com/ipodtouch/features/ibooks.html

5. Blackboard.com. (2010, June 15). Blackboard releases mobile learning apps for all major mobile platforms. Retrieved from http://www.blackboard.com/About-Bb/Media-Center/Press Releases/Archive. aspx?releaseid=1438039-

6. Block, R. (2007, June 3). iPhone release date confirmed: Yours on June 29th. Engadget, Retrieved from 
http://www.engadget.com/2007/06/03/iphone-release-date-confirmed-yours-on-june-29th/

7. Bradley, T. (2010, April 29). HP purchase of Palm paves way for WebOS tablet. PCWorld, Retrieved from http://www.pcworld.com/businesscenter/article/195252/hp_purchase_of_palm_paves_way_for_webos_tablet.html

8. Corbeil, J. R., \& Valdés-Corbeil, M. E. (2007). Are you ready for mobile learning? EDUCAUSE

Quarterly, 30(2), Retrieved from http://www.educause.edu/EDUCAUSE+Quarterly/EDUCAUSEQuarterlyMagazineVolum/ AreYouReadyforMobileLearning/157455

9. Dyson, L. E., Raban, R., Litchfield, A., \& Lawrence, E. (2009). Addressing the cost barriers to mobile learning in higher education. International Journal of Mobile Learning and Organisation, 3(4), Retrieved from http://goo.gl/BR0sF

10. EDUCAUSE Conversations. (2011). Bryan Alexander on mobile devices in higher ed [Web]. Available from http://www.youtube.com/watch?v=YMRvDcgeXsI\&feature=player_embedded

11. EeePC. (2011, May 9). Asus Eee Pc 1000he information. Retrieved from http://www.eeepc1000he.com/EeePC1000HE_info.html

12. Ganapati, P. (2008, September 23). T-mobile’s G1 Android phone: Neither open nor exciting. Wired.com Gadget Lab, Retrieved from http://www.wired.com/gadgetlab/2008/09/g1-android-phon/

13. Ganapati, P. (2010, September 2). Samsung introduces 7-inch tablet to rival iPad. Wired Gadget Lab, Retrieved from http://www.wired.com/gadgetlab/2010/09/first-look-samsung-tablet/

14. Gate6.com. (2010, June 24). Social media's continuous evolution. Retrieved from http://www.gate6.com/Blog/interactive/interactive-blog/June-2010/Social-Media-s-Continuous-Evolution.aspx

15. Google.com. (2004, April 2004). Google gets the message, launches Gmail. Retrieved from http://www.google.com/press/pressrel/gmail.html

16. Herrington, J., Herrington, A., Mantei, J., Olney, I. W., \& Ferry, B. (2009). New technologies, new pedagogies: Mobile learning in higher education. Retrieved from http://ro.uow.edu.au/newtech/

17. Jason, M. (2010, January 5). Google unveils the Nexus One, coming to Verizon in spring 2010. Daily Tech, Retrieved from http://www.dailytech.com/An+iPhone+Slayer+Google+Unveils+the+Nexus+One/article17291.htm

18. Kukulska-Hulme, A.; Sharples, M.; Milrad, M.; Arnedillo-Sanchez, I.; \& Vavoula, G. (2009). Innovation in mobile learning: A European perspective. International Journal of Mobile and Blended Learning, 1(1), pp. 13-35, Retrieved from http://oro.open.ac.uk/12711/1/IJMBL_pre\%2Dprint_19_Dec_2008.pdf

19. Lee, N. (2007, May 30). iPhone is open to third-party apps, says Jobs. CNET News Crave, Retrieved from http://news.cnet.com/8301-17938_105-9724168-1.html

20. Microsoft News Center. (2010, February 15). Microsoft unveils Windows Phone 7 Series. Retrieved from http://www.microsoft.com/presspass/press/2010/feb10/02-15mwc10pr.mspx

21. Miles, G. (2009, April 1). Blackberry app world open for business. Macworld, Retrieved from http://www.macworld.com/article/139769/2009/04/blackberryapp.html

22. Moodle.com. (n.d). New project: MLE-Moodle (Moodle for mobile phones). Retrieved from http://tracker.moodle.org/browse/CONTRIB-714

23. Patel, N. (2007, November 21). Kindle sells out in 5.5 hours. Retrieved from http://www.engadget.com/2007/11/21/kindle-sells-out-in-two-days/

24. Patel, N. (2009, January 8). Palm announces WebOS platform. Engadget, Retrieved from http://www.engadget.com/2009/01/08/palm-announces-web-os-platform/

25. Pogue, D. (2009, May 6). Wi-fi to go, no cafe needed. New York Times: Personal Tech, Retrieved from http://www.nytimes.com/2009/05/07/technology/personaltech/07pogue.html?pagewanted=1\&_r=1

26. Reisinger, D. (2011, March 2). Report: BlackBerry PlayBook to launch April 10. CNET News: The Digital Home, Retrieved from http://news.cnet.com/8301-13506_3-20038256-17.html

27. PCMag.com. (2010, September 7). Nokia to launch N8, E7 Smartphones in September. PCMag.com, Retrieved from http://www.pcmag.com/article2/0,2817,2368756,00.asp

28. Savov, V. (2011, February 6). Best Buy ad prices Motorola Xoom at $\$ 88$, affirms February $24^{\text {th }}$ launch date. Engadget, Retrieved from http://www.engadget.com/2011/02/06/best-buy-ad-prices-motorola-xoom-at-800affirms-february-24th/

29. Savov, V. (2011, March 2). The iPad 2. Engadget, Retrieved from http://www.engadget.com/2011/03/02/the-ipad-2/

30. Schonfeld, E. (2009, December 14). First 4g mobile network launched in Sweden. TechCrunch, Retrieved from http://techcrunch.com/2009/12/14/4g-mobile-network-sweden-teliasonera/ 
Volume XII, No. 2, pp 142-152, 2011

31. Silverman, D. (2008, July 11). iTunes 7.7 is out, Apple App Store is open for business. TechBlog, Retrieved from http://blog.chron.com/techblog/2008/07/itunes-7-7-is-out-apple-app-store-is-open-for-business/

32. Smillie, D. (2010). Digital lift off. Forbes, Retrieved from http://www.forbes.com/2010/03/07/advertising-webads-digital-business-media-outsell.html

33. SoftChalk.com. (2011). Sneak peak: Be the first to experience the amazing new features of Softchalk 7. Retrieved from http://www.softchalk.com/eNews/enewsMay2011.html 